\title{
TTR
}

Traduction, terminologie, rédaction

\section{It's All in the Name: Redressive Translation, Passive/Active Redressive Translation}

\section{Amanda Leigh Cox}

Volume 32, numéro 1, 1er semestre 2019

Traduction et politique(s)

Translation, Politics and Policies

URI : https://id.erudit.org/iderudit/1068020ar

DOI : https://doi.org/10.7202/1068020ar

Aller au sommaire du numéro

\section{Éditeur(s)}

Association canadienne de traductologie

ISSN

0835-8443 (imprimé)

1708-2188 (numérique)

Découvrir la revue

Citer cet article

Cox, A. L. (2019). It's All in the Name: Redressive Translation, Passive/Active Redressive Translation. TTR, 32(1), 231-258. https://doi.org/10.7202/1068020ar

\section{Résumé de l'article}

La résistance traductive est un moyen bien connu et accepté par les minorités et les groupes linguistiques/culturels opprimés d'accéder au pouvoir, à l'action et à la réparation culturelle (voir Niranjana, 1992; Simon, 2005; Bandia, 2008; Cox, 2009; Tymoczko, 2010). Pourtant, malgré tout le bien qu'apportent les "retraductions ", elles restent associées à un terme qui efface leur signification en les assimilant au simple fait de « traduire à nouveau ». Cet article plaide pour l'adoption d'un nouveau terme, " traduction réparatrice », pour remplacer le terme « retraduction » dans les contextes où la résistance réparatrice en traduction est manifeste. Il examine et définit deux variétés de traduction réparatrice, à savoir la traduction réparatrice active et la traduction réparatrice passive. En adoptant le terme " traduction réparatrice " pour englober les caractéristiques présentes dans les textes traduits qui témoignent d'une volonté de résistance politique et qui offrent aux culturelles minoritaires et minorisées une façon de guérir, une clarté et une force renouvelées sont associées à ces traductions. Les lecteurs, chercheurs, traducteurs, écrivains et activistes peuvent ainsi partager un terme commun pour ces articulations/manifestations essentielles de la résistance.
Ce document est protégé par la loi sur le droit d'auteur. L'utilisation des services d’Érudit (y compris la reproduction) est assujettie à sa politique d'utilisation que vous pouvez consulter en ligne.

https://apropos.erudit.org/fr/usagers/politique-dutilisation/ 


\title{
It's All in the Name: Redressive Translation, Passive/Active Redressive Translation
}

\author{
Amanda Leigh Cox \\ Independent Scholar
}

\begin{abstract}
Resistance in translation is a well known and accepted means for minorities and oppressed linguistic/cultural groups to access power, agency, and cultural repair (see Niranjana, 1992; Simon, 2005; Bandia, 2008; Cox, 2009; Tymoczko, 2010). Yet for all the good "retranslations" do, they remain yoked to a name that erases their significance by collapsing it with the simple act of "translating-again." This paper argues for the adoption of a new term, "redressive translation," to replace the term "retranslation" in contexts where redressive resistance in translation is manifest. It examines and defines two distinct varieties of redressive translation, namely "active redressive translation" and "passive redressive translation." By adopting the name "redressive translation" to identify characteristics present in translated texts that resist politically and offer minority/minoritized cultures a means of healing, new clarity and strength can be brought to these translation offerings, enabling readers, researchers, translators, writers, and activists alike to share a common term for these essential articulations/manifestations of resistance.
\end{abstract}

Keywords: redressive translation, resistance in translation, cultural repair, retranslation

\section{Résumé}

La résistance traductive est un moyen bien connu et accepté par les minorités et les groupes linguistiques/culturels opprimés d'accéder au pouvoir, à l'action et à la réparation culturelle (voir Niranjana, 1992; Simon, 2005; Bandia, 2008; Cox, 2009; Tymoczko, 2010). Pourtant, malgré tout le bien qu'apportent les «retraductions », elles restent associées à un terme qui efface leur signification en les assimilant au simple fait de «traduire à nouveau». Cet article plaide pour l'adoption d'un nouveau terme, «traduction réparatrice», pour remplacer le terme "retraduction" dans les contextes où la résistance réparatrice en traduction est manifeste. Il examine et définit deux variétés de traduction réparatrice, à savoir la traduction réparatrice active et la traduction réparatrice passive. En adoptant le terme «traduction réparatrice» pour englober les ca- 
ractéristiques présentes dans les textes traduits qui témoignent d'une volonté de résistance politique et qui offrent aux culturelles minoritaires et minorisées une façon de guérir, une clarté et une force renouvelées sont associées à ces traductions. Les lecteurs, chercheurs, traducteurs, écrivains et activistes peuvent ainsi partager un terme commun pour ces articulations/manifestations essentielles de la résistance.

Mots-clés : traduction réparatrice, résistance en traduction, réparation culturelle, retraduction

\section{Introduction}

Retranslation, commonly known as the act of producing another iteration of an already-translated text, has a long and storied history. As documented by Şhenaz Tahir Gürçağlar (2008), it has been analyzed for some time, initially with a focus on its usefulness within genres where it could feasibly appear (e.g., literary, technical, scientific, administrative). The retranslation hypothesis, put forward in Antoine Berman's 1990 seminal essay published in Palimpsestes, asserted that only through retranslation(s) can literary source texts become complete, drawing the translator ever closer to a source text's language and culture with every iteration/retranslation. However, the hypothesis was critiqued for its oversimplification of the complex cultural and historical factors inherent to the translation project it purported to undertake.

Traditional views of retranslation that were common in the 1990s have been challenged in a number of case studies published during the first decade of the twenty-first century [...]. These studies have revealed the complexity of the phenomenon and the need to embed it within a broader discussion of historical context, norms, ideology, the translator's agency and intertextuality. (Baker and Malmkjær, 2008, p. 233)

The theoretical and practical foundations of retranslation (as a political or resisting effort) were emboldened and strengthened during Translation Studies' postcolonial turn and onwards, with examinations of the topic provided in research by Tejaswini Niranjana in Siting Translation (1992), which centered on retranslation in India; Maria Tymoczko in Translation, Resistance, Activism (2010), where retranslation is cited as a point of access to agency for minorities; and Paul Bandia in Translation as Reparation (2008), where African identity is asserted via new literary forms. In general, research tends to support that " $[\mathrm{r}]$ etranslation in the field of literature is usually regarded as a positive phenomenon, leading to diversity and a broadening of 
the available interpretations of the source text" (Baker and Malmkjær, 2008, p. 233), and the latter point is not up for debate here. As I use the term in this article, retranslation refers strictly to manifestations within literature/literary texts, where it is or has been used to indicate the concept of translation practice ${ }^{1}$ helping to cultivate or foster aspects of political or cultural redressive resistance, and later cultural healing and/or reconciliation. However, retranslation-as-redressive resistance is lexically identical to retranslation-as-translating-again, despite important differences in purpose, execution, orientation, and very obvious ideological and methodological differences. Given that in current Translation Studies theory, politically oriented retranslation is now accepted and acknowledged as being necessarily tied to historical, cultural, and social elements in terms of both source and target text, it is logical that retranslation-as-a-cultural-or-politicaleffort differentiate itself to reflect its unique purpose-instead of simply using the undifferentiated term "retranslation," and risking confusion and/or obfuscation. In this article, I argue for this very differentiation, and offer "redressive translation" as this new term. After a background justifying redressive translation as the new term (versus other possible terms or classifications), redressive translation will be contextualized. Redressive translation is a meta-classification, thus nuance will be added by defining active and passive redressive translation as manifestations of a variety of resistance in translation with distinct links to minority/minoritized cultures, with examples from literature.

\section{"What's in a Name?" Contextualizing Redressive Translation}

Shakespeare's Romeo and Juliette knew the weight a name can carry, and I agree: before continuing further, I will henceforth use the term "redressive translation" to refer to texts that manifest redressive resistance, and which are acts of minority/minoritized cultures translating and/or translating-again for political purposes, and use the term "retranslation" for "translating-again for non-political or nonredressive purposes." For example, according to the latter definition, a retranslation could be a non-contentious, apolitical reissue or update of a work of literature, such as the Norton Critical Edition of Joseph Conrad's Heart of Darkness (Armstrong, 2016) versus the

1. "Translation" is used here to indicate the word-to-word, interlinguistic transfer of meaning via print medium, as per the definition popularized by Roman Jakobson (1959). 
original 1899 edition. Within this article, the definition of "politics" is wide and encompasses acts performed by individuals as well as societies:

Politics is the activity through which people make, preserve and amend the general rules under which they live. [...] Politics is better seen as a search for conflict resolution than as its achievement. (Heywood, 2013, p. 2)

In redressive translation, a defining element is that the "source text" (the latter a status conferred by colonial/settler discourses) often has its origins in the reality of minoritized, oppressed cultures. For example, indigenous cultural stories are taken by empire, and translated into written texts for colonial consumption. Colonial/settler era processes often include cultural replacement strategies that seek indigenous ${ }^{2}$ cultural destruction (Wolfe, 1998). In the present era of reconciliation, we recognize that embodied in the creation of this so-called "source text" is an act of cultural sabotage which subverts minority cultures, essentializing and Othering them into near-oblivion. Given that we largely remain in settler-era established social, cultural, and political systems, we and these systems have difficulty acknowledging the presence and status of what came before colonization and settler arrival. As such, these harmful texts retain their status as "source texts," when they are in fact, translations. To avoid confusion, henceforth in this paper, "indigenous source text" is used to refer to pre-colonial texts, and "imperial source text" will refer to texts generated by empire or oppressive force. Determining the genuine indigenous source (as a text or an oral offering) can seem an impossible task, and certainly one that merits more space than can be provided here; in some cases, original indigenous sources have been lost forever. Some identifying characteristics of indigenous source texts can be their subject matter (origin stories and/or stories that address fundamental societal shifts), age (most texts will be or should be pre-colonial/pre-settler in terms of origin), social value (stories will be highly valued by minority/ minoritized cultures and communities, and they will identify with them). It goes without saying that another indicator is the presence of a body of active and/or passive redressive translations- the latter which seek to reveal and re-value the authentic indigenous source text.

2. "Indigenous" is used here in the broad sense of: "produced, growing, living, or occurring natively or naturally in a particular region or environment" (Merriam-Webster Dictionary, n.d.). When used in this non-specific fashion, it does not require a capital letter. 
All of the above in mind, so long they fulfill the criteria defined in this paper, redressive translation includes translations/retranslations, wherein a minority/minoritized culture takes an imperial source text and redressively translates it.

Translation Studies has traditionally used four categories for the phenomenon of translating-again for political reasons, each with their own characteristics. In the first two iterations of the term (Niranjana and Bandia's usages), in addition to the practical work of contesting source texts/narratives and supplying authentic minority culture narratives, these redressive retranslations provide the once-powerless with a means of voice and visibility, releasing them in part from Gayatri Spivak's status of subaltern (1988), where they are excluded from power or influence. Newfound voice and visibility through redressively translated texts serve to subvert colonial authority because these texts originate from a specific, authentic source: minorities that have experienced colonial/imperial oppression and are speaking out against it in the effort to regain themselves. In the remaining two iterations of the term (Venuti, 1998; Tymoczko, 2010; Simon, 2005, 2014; Mezei, Simon and Flotow, 2014), the translator appears to act alone, or at least without necessarily needing community support or acceptance, which can potentially cause serious implications in terms of whether or not translators are acting on behalf of themselves or others. This can cause issues of agency, where translators take the place and voice of the oppressed, instead of working with that community so that the community's distinct vision and culture are articulated.

In my view, "retranslation" as used by Niranjana (1992) is the most problematic because it conflates two very different phenomena under the same name: translating-again and translating-again for political reasons. Niranjana used the term in 1992 to refer to translations by minority, marginalized cultures in postcolonial contexts, who seek to contest and rectify erroneous imperial source texts and narratives heavily imbued with Orientalist (Said, 1978) and essentialist renderings of their culture. Her critique of translation is that it replicates asymmetrical power relations, and brings along its own largely Western European philosophical baggage; retranslation was one remedy to these problems:

[...] translation comes into being overdetermined by religious, racial, sexual, and economic discourses. It is overdetermined not only because multiple forces act on it, but because it gives rise to multiple practices. (Niranjana, 1992, p. 21) 
Yet, "retranslation" leaves those reading the text(s) unaware of whether what she calls "retranslation" is a translating-again effort, or a translating-again-for-political-reasons effort. How would one know what orientation is being taken unless already familiar with the source text, and its surrounding cultural, political, and historical context? "Translation functions as a transparent presentation of something that already exists, although the 'original' is actually brought into being through translation." (ibid., p. 3). Translating-again-for-politicalreasons is far too important an effort to hide within the broad and vague term "retranslation."

Reparative translation, as put forth by Bandia (2008), comes closer to what redressive retranslation describes, because it refers to writing-translating and translating-again for political, or, as he calls it, reparative reasons. Bandia cites what he calls reparative translation's power in the African and pan-Caribbean contexts, where it gives rise to original forms of fiction, writing, and translation, which are a combination of indigenous and colonial elements. For example, texts would retain indigenous elements such as traditional names of kinship, or the names of important cultural or social items, and place these indigenous elements within the framework of Western translation practice, in a translated text. This creates a text that at once resists colonial domination by celebrating, highlighting, and inserting authentic African/Caribbean cultural terms, but also adheres in many ways to typical Western translation traditions. These texts resist dynamically, and provide a more complete image of African and panCaribbean postcolonial culture. Yet, Bandia's theory leaves many questions unanswered. Are these dynamically resisting reparative texts what Lawrence Venuti refers to as "foreignizing translations" (1998)? Most critically, does reparative translation purport to be a one-size fits all model or solution? Can a single reparative translation repair all the damage done by a harmful source text? What if no real cultural, political, or social repairs are made after the reparative translation? What if reparative translation is incomplete in its task, and only repairs for some groups, but not others? Then there is the question of what a reparative translation does with a harmful source text-does it wholly replace and/or erase it? Other questions include: How well or poorly does reparative translation tolerate the tension between the harmful source text and the reparative target text? Redressive translation seeks to address these lacunae. Bandia's reparative translation also seems to 
imply that repairs occur by virtue of a "postcolonial"3 writer-translator moving back and forth between their own native language and culture to the imposed language and culture.

$[\ldots]$ it is not an exaggeration to claim that, by its very hybrid nature, the language of Euro-African fiction has been fashioned partly through a process of translation. African intercultural writing is highly indebted to traditional African discourses, traces of which manifest themselves as a kind of subtext to the European-language fiction. (Bandia, 2008, p. 121)

So, aside from the fact of multiculturalism inherent to the above experience, there is no indication of what, specifically, it repairs culturally, or if we even conceive of repair as a verb. Bandia also mentions $1^{\text {st }}$ and $2^{\text {nd }}$ level translation as an internal process of translation within writer-translators as they move in the world. However that seems rather more similar to Homi Bhabha's notion of hybridity (1994) than it does to a translation that repairs a culture or society. Bandia's concept discusses a writer-translator-a single person who contains and embodies both a "writer"-ness and a "translator"-ness who produces a text, which seemingly skirts the translation proper $^{4}$ process as we know it.

"Resistance translation" is another term and concept that comes close to a solid alternative, yet falls short. Resistance translation refers to Venuti's foreignizing and domesticating paradigm (1998). Domestication occurs when the text closely conforms to the target culture, which often involves source text/source culture information loss. The flipside to this is foreignization, where the target text includes source text/source culture information, choosing to break target language conventions to preserve source text meaning. Resistance translation incorporates a political orientation; resistance is visible within the text, and affects both linguistic and cultural aspects of translation. "Foreignizing translation in English can be a form of

3. "Postcolonial" is a contentious term in our era of reconciliation. This usage is from Bandia's work. In the attempt to accommodate the dual realities of academic culture that has long adopted the term "postcolonial" while also acknowledging that many nations are experiencing a period of reconciliation with Indigenous Nations, I will use various forms of "settler/postcolonial" to acknowledge original indigenous presences, the arrival of colonizing settlers, and also the ongoing maintenance of settler/colonially established political, social, and cultural structures.

4. Translation proper here refers to the linguistic transfer of a message or information from one language and culture (source text) to another language and culture (target text). 
resistance, ethnocentrism and racism, cultural narcissism and imperialism in the interests of democratic geopolitical relations" (Venuti, 1998, p. 16). However, resistance is mainly manifested on the grounds of fluency: "Foreignizing translation signifies the differences of the foreign text, yet only by disrupting the cultural codes that prevail in the translating language" (ibid., p. 15). This presents some problems, as fluency alone is not the only criteria for what it is to resist, and it is unclear whether or not there is a universal standard for readability that cuts across cultures. A culture's conception of fluency may differ, giving a sort of "false positive" result of seeming to be a foreignizing translation, when in fact it could be considered a fine example of literature, instead of being jarring or uncomfortable for the reader. Another question is what, other than readability, is being resisted? Further, lack of fluency for some audiences may jar the reader into acknowledging they are reading a translation, but this might take on the feel of an "activist translation" even if the translation itself does not seek this result. Cultural codes are another potentially difficult issue to mitigate. For example, what if a resisting, foreignizing translation offends the cultural codes of the culture that seeks to use foreignizing to resist, and as a result of this cultural code offense, distances itself from that foreignizing translation? In such a case, does that foreignizing translation accomplish its goal or merely "offend" everyone?

“Activist translation” (e.g., Simon, 2005, 2014; Baker, 2006; Tymoczko, 2010) is also a good candidate for a replacement term, but nonetheless not quite sufficient.

[...] "activist translation." This is a term whose parameters can be very broad. More than subjective interventions, activism refers to work by translators that is shaped by a pattern of social or political beliefs. [...] activist translations have a more proactive intention. They wish to open a discussion with a new public. (Simon, 2014, p. 52)

Simon $(2005,2014)$ and Tymoczko (2010) both assert that translators make political choices when they choose to translate (or not translate) a text. In activist ${ }^{5}$ translations, translators are said to act as agents for their own perspective or purposes, or for those of others (either individuals or party(ies)) - making these translations necessarily political in orientation. However, what, other than advocating, is their purpose? Activist translations are frequently bold, assertive, and seek

5. Sometimes also referred to as "protest/protesting translations." 
to disrupt — all of which are interesting and useful strategies, but can potentially cause confusion as to their purpose, or the subject of their activism. Activist translations may also alienate the very people the translation seeks to advocate for, because activism and protest are embedded in social and cultural mores (or the transgression of social or cultural mores). Activism on the whole can also mean different things to different people or groups, all of whom have various stakes in any given debate or context.

So now we come to "redressive translation," which accommodates the lacunae that these other terms leave. Given similarities of context and purpose, redressive translation can be considered a type of resistance in translation, as both can conceivably be found anywhere translation and/or conflict co-exist. In terms of hierarchy (see Figure 1), resistance in translation is generalized, and encompasses redressive translation, as evidenced by the former's wide distribution, variety of forms, and presence in multiple contexts, from India (Niranjana) to the pan-Caribbean and Africa (Bandia), to Ireland (Tymoczko), North America, South America, and so on. Is all resistance in translation actually redressive translation in disguise? No, because resistance in translation has a far wider and more general distribution and includes a variety of forms, whereas redressive translation has specific criteria to fulfill in terms of its: origin as an indigenous source text that was translated into an imperial source text; use as a dominating tool in the settler/postcolonial context; reception by the community that generated them; and requisite multiple iterations.

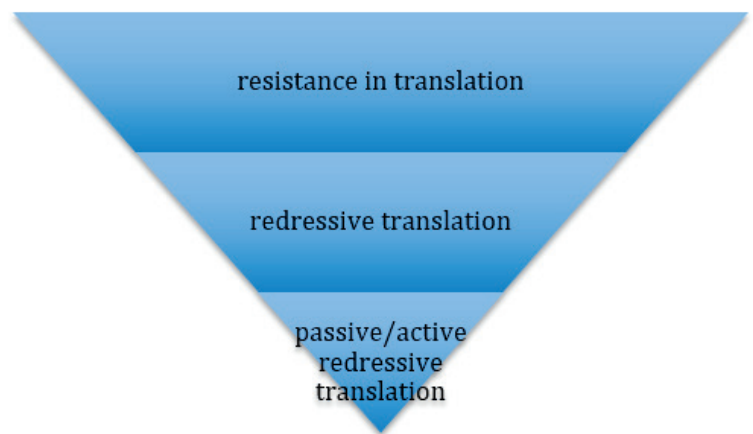

Figure 1. Resistance in translation hierarchy 
Redressive translation is translating/translating-again for political reasons, where polyphony spurs on silenced minority voices. It accommodates and requires multiple, successive and/or simultaneous iterations that foster polyphony, the latter acting as a mechanism to destabilize ${ }^{6}$ the authority of the imperial source text by overwhelming it with texts that challenge it. Polyphony is a polysemic term which originated in musicology. It has been used in linguistics and literature to indicate a concordance of voices, which at times leads to harmony, and at times leads to cacophony. It asserts that a speaker may articulate their own views, and their views may also contain the views of others participating in the same discourse. Polyphony is often used in highly interdisciplinary contexts, and is appropriate for translation, given that:

Since it is a theory that aims at explaining relationships between linguistic forms and the numerous interpretations to which they give rise, it is applicable in any academic discipline in which text and discourse interpretation play a significant role. (Nolke, 2017, p. 195)

This article uses Mikhail Bakhtin's (1984) iteration of polyphony, which referenced Dostoevsky's work, where the multi-voiced-ness that polyphony embodies and reveals provides a fuller understanding of Dostoevsky's characters' experiences and the overarching context of the book. In redressive translation, polyphony destabilizes the imperial source text and its attached dominant oppressive discourses with its plurality of voices, narratives, and translations, as per Bakhtin: "a plurality of independent and unmerged voices and consciousnesses, a genuine polyphony of fully valid voices [...] with equal rights and each with its own world ${ }^{7}$, combine but are not merged in the unity of the event" (1984, p.6)-wherein "an event" is an act of redressive translation or resistance. Redressive translations provide a jumping off point for polyphony because their existence questions established renditions of imperial history and disputes colonial interpretations of minority cultures. Further, they compete with imperial narratives for authority over the past while at the same time, provide a voice for the previously silenced subaltern. In a settler/postcolonial and polyphonic context, redressive translations articulate and embody

6. In Derrida's terms (1976), one may also consider this destabilizing as an increase in the "undecidability" that surrounds the culture about which the source text was written.

7. In redressive translation, polyphonic voices have equity in terms of status-which may seem idealistic, but is part of the destabilizing and undecidability mechanism. 
narratives of a nations' experiences of itself, a foundational element of collective memory - the latter defined by Maurice Halbwachs (1993) as the meta-narrative of a nation or society, supported in part through "imagined community," Benedict Anderson's (2006) term for the sentiment of shared national identity across a nation. The two forms of redressive translation (to be discussed shortly) also act on two temporal scales. Immediately upon creation, redressive translations refute claims and recount minorities' lived experiences of colonization. Secondly, over time, they document transitions from settler-era/ colonization into decolonization, self-realization, and the rectifying of recorded history. Note that redressive translation (in particular passive redressive translation, to be discussed) can also be a part of failed independence movements, offering proof of minorities' desire for change and self-actualization.

Former empires could attempt to use redressive translation to make amends for their historical actions by creating faux-redressive translations-translation mea culpas that attempt to clear empires from historical wrong-doing, but are, in reality, revisionist. ${ }^{8}$ Such translations would likely be recognizable because authors would likely be imperial proxies of some sort, ${ }^{9}$ versus members of minority/ minoritized cultures and communities. Faux texts would also likely not be accepted by nor resonate with minority/minoritized cultures, and would doubtless focus on imperial damage control and restoring status to empires, versus genuine redressive translations that challenge imperial authorities to admit their domination, manipulation, and outright lies. Even faux-redressive translations would ultimately reveal imperial errors, shortcomings, and ignorance, because these faux texts would ultimately reinforce the notion that empires have historically been erroneous and ill informed in terms of understanding other cultures (as evidenced by faux redressive translations, themselves!). The production of faux redressive translations may even help to undermine any vestiges of imperial authority through polyphony, calling into

8. Note that official government apologies for past acts are not translations/ retranslations of indigenous source texts, therefore cannot be considered faux redressive translations. It is interesting to note, however, that like faux redressive translations, minority communities often do not perceive official apologies as redressive.

9. Imperial proxies would have status or power conferred to them by empire, and certainly would have more power than minority/minoritized communities. For example, a white author could not produce a redressive translation of a First Peoples' story in Canada, given that white Canadians have historically and typically had more social, political and financial advantages than First Peoples. 
question imperial validity and honesty. Genuine redressive translation by definition must originate from within minorities and/or oppressed cultures, by those who seek to provide their cultures with voice; it is therefore critical that these translation offerings be accepted by this same culture as representative of their authentic selves and voice.

What's in a word? Why use "redressive" versus adjectives such as "reparative," "corrective," or "rectifying"? "Redress" is both a verb and a noun, an action and a product. The Merriam-Webster Dictionary defines the verb as "to set right, remedy, compensate; to remove the cause of a grievance" (n.d., n.p.). In archaic usage, to redress means "to requite (a person) for a wrong or loss; to heal" (ibid.). As a noun, "redress" is "a relief from distress, a means or possibility of seeking a remedy; a compensation for a wrong or loss, an act or instance of redressing" (ibid.). As a verb it is the enacting of actions that are required to bring about or result in the compensatory object/noun, and as a noun, it represents compensation for or repair of a preexisting grievance or injury. In political contexts, the term "redress" initially indicated the need for the restitution of stolen or looted property; over the years, the term has been rightfully extended to also include cultural, psychological, and physical harms, versus merely property-based harms. As a result, it can presently be used in a civil rights context to describe the provision of official apologies for state or government misdeeds, as well as payments made to groups or individuals as a means of addressing systemic or institutional foul play (Bascara, 2003). The term "redress" is superior to others because terms that imply correction or rectification bring judgment, absolute notions (e.g., correct or incorrect), and polarities. This is problematic because contexts where redressive translations are needed most are generally those where the deconstruction of binaries is essential to healing and/ or peace creation. Furthermore, redressive translation acknowledges that the act (verb) of redressing must be undertaken first, in order to create the products (noun; the translations), which in turn must be acknowledged and accepted by minority communities as part of minorities' own narratives ${ }^{10}$, thereby bolstering usefulness in terms of cultural repair.

To sum up, redressive translation comprises the concept of polyphony because it requires that multiple redressive translations be produced. Polyphony leads redressive translation to be highly

10. This process and pathway are examined in more detail in descriptions of active and passive resistance in translation in Cox (2009). 
productive, fostering numerous texts that articulate a variety of positions that now-voiced minorities may choose to take. Far from being superfluous, this textual variety begins to populate the site where the imperial source text's oppressive essentialist rendering was once dominant, destabilizing the latter while increasing the prominence and notoriety of new redressive translations and the perspectives they bring. Redressive translation's success is measured by the degree of acceptance these translations achieve within the communities they speak with (not for). Redressive translation offers the desire for reconciliation, but does not guarantee that it alone is the mechanism to provide it; it is meant to be used in concert with other measures, (other activist or protest translations; community, administrative, and/ or other peace-building efforts). In terms of terminology and naming, "redress" is sought where an injury has occurred: an acknowledgement of trauma, and response to it. In redressive translation, this means returning to the indigenous source text and initiating a dialogue about the nature of imperial source text, and making space for minority/ minoritized communities' polyphony.

\section{Passive and Active Redressive Translation}

There are two distinct manifestations of redressive translation: passive and active. These two forms occur during specific points on the trajectory towards postsettler/postcolonialism, and each has specific textural features. Passive redressive tends to occur first, followed later by active redressive; both terms and their features are described below, with examples.

Passive redressive translation works under oppressive authority's radar out of both necessity and choice, occurring where minorities' assertions of identity, power, and culture are required or choose to remain covert-such as in pre-revolutionary contexts, or contexts where minorities are unable to reliably secure a means of production without cooperation from oppressors. Passive redressive translation can also be found in contexts where overt resistance could be dismissed, decried, or destroyed outright by the powers-that-be. Due to the above conditions, passive redressive translation must be clever and far less bombastic than active redressive translation (definition to follow). Changes manifested in the translated text are far subtler and understated, relying on recognition by the communities they speak with. Particularly important in this variety of resistance in translation is the latter's acceptance as reflective of the minority cultures who 
require redress. For example, if the redressive translation is created from an indigenous source text deemed too sacred or unchangeable in some way, the community is unlikely to accept its alteration, because it alters or destroys what is considered in short supply - texts reflective of subaltern or minority perspectives. If a text is selected that the minorities in question are unlikely to seek out and read with interest or care, once again any exercise of redress is rendered moot because it lacks cultural capital (Bourdieu, 1986). Further, if the redressive translation is expressed in a way that contradicts or defies national or social mores of artistic or personal expression (such as bombast where subtlety is valued), the attempt to articulate resistance will also fail. Passive redressive translation tends to appear as a translation which may:

[...] be seen simply as the work of an overzealous or inexperienced translator, since its focus on faithfulness may erroneously be viewed as the work of someone who subscribes to the novice and only-selectivelyappropriate word-for-word method of translating. The risk of this interpretation increases particularly if the translation comes early on in the translator's career, which, in cases where majority regimes are about to be overthrown, could well be the case. (Cox, 2009, p. 26)

In terms of translation features, what on the surface seems to be strict adherence to the notion of "translator fidelity" in fact mocks imperial/oppressive essentialist narratives by repeating and amplifying erroneous pronouncements and information with its faithfulness. In this way, it subverts oppressive authority's attempt to essentialize by displaying it in this new passive redressive translation as farcical and inadequate. Elements such as the retention of obvious and acknowledged historical inaccuracies, highly repetitive structures or phrases, exaggerated Othering and/or essentialized characters all may be seen in this form of resistance in translation. Such a translation passes under the radar of authority because on the surface it fulfills the criteria for a "good translation"11 by transmitting all (potentially exhaustively!) that the imperial source text contains. In these translated texts, more evidence of passive redressive elements can be found in subtle, embedded "clues" identifiable and decipherable only by insider/minority cultures-cultural tip-offs. To this point, passive

11. "Good translation" here refers to a layman's assessment of translation quality where the message has been rendered from source to translated text; this is by no means an assessment of quality made by a translation scholar or researcher. A categorization of "good translation" in academic circles can be a very contentious thing! 
redressive translation becomes slightly tricky: insider/minority culture readers require at least rudimentary bilingualism or fluency ${ }^{12}$ in the translating language to find clues left by the resisting translator. In addition to bilingualism, readers would also need some cultural literacy in terms of both their own and the oppressive culture to determine what was straightforward translation, and what was passively resisting translation. Complex as this may initially sound, such criteria can indeed be found in numerous settler/postcolonial or other oppressive contexts, given that part of colonial rule includes the imposition of imperial language and culture which displaces indigenous varieties to varying extents. For all its complex caveats, passive resistance in translation can result in texts that balance "harmless" fidelity and embellishment with cultural clues to create highly readable texts that appeal to those reading for pleasure, and those reading (perhaps interloping culturally) with an understanding of what the translation may represent in the process of decolonization. In this way, these texts can endure and continue their work as resisting oppression and empire long after the "struggle on the ground" may have ended. Passive resistance in translation manifests itself in a subtle, cagey manner typified by faithful-seeming translations that in fact amplify the inadequacy and illegitimacy of imperial assumptions, while simultaneously leaving hints for those within minority cultures to recognize themselves and embrace a message of resistance. In this way, they are able to pass undetected, all the while helping bolster the ability of the subaltern to access power in the hope of an eventual full and unfettered articulation of resistance and decolonization.

Active redressive translation seeks to outright refute colonial authorities (or other oppressive authorities) and feels no responsibility to maintain the imperial source translation's structure or format. Simply put, these translations may appear as entirely re-worked, re-written or re-imagined departures from the source text and may even create dynamic, ingenious, new forms. ${ }^{13}$ They actively and obviously engage in colonial critique using agency stemming from within the oppressed

12. Bilingualism or fluency in reference to two languages or cultures-either in the literal sense or in a more figurative sense meaning in-depth or intimate knowledge of the aforementioned.

13. An example of "novel translation forms" that resist can include the insertion of Indigenous language in translated texts, or structural changes that reflect a nation's oral history heritage or reflect sociocultural organization. See Bandia (2008) and Tymoczko (1999). 
cultures in question, resisting and challenging the structure and content of narratives that embody colonial claims of authority and domination. With this overt show of opposition to empire in mind, translations of this type tend to originate in contexts where formerlycolonized nations are far along on the path to regaining means of cultural production, so there is reduced fear of possible retribution when engaged translators craft redressive translations. Active redressive translations exist to challenge and defy existent narratives; just as importantly, they enable the once-oppressed to articulate their own visions of their cultures and creativity. Given that nations creating these translations are advanced in terms of independence, these texts shift origin story narratives, and further increase polyphony. Ergo, the caveat of reception holds: minority communities that espouse active redressive resistance must accept and acknowledge the translated texts as reflective of their own experiences and cultures. Acceptance, combined with the clarity of a redressive resisting message and the possibility of new and unique translation forms, ensures the longevity of redressive texts and helps establish them as parts of a newly forming post-settler/postcolonial canon,

Active resistance $[\ldots]$ might be considered the preferred method of resistance in translation since its message is readily accessible and obvious to those receiving/reading texts. The longevity of actively resisting translations can be more or less ensured, since they may be considered some of the more sophisticated indicators of unrest in the colonialized population in their search for independence [...]. (Cox, 2009, p. 34)

Active redressive translation boldly asserts the subaltern's right to voice, and firmly opposes authority; it appears in translations as dynamic, creative, or drastic changes to the imperial source text and requires positive reception from minorities it dialogues with to ensure its longevity, endurance, and polyphony.

\section{Passive and Active Redressive Translation: Practical Examples Passive Redressive Translation}

To illustrate the passive redressive translation phenomena, I will cite Pamphile LeMay's Évangeline (1870), the Canadian French-language translation of American Henry Wadsworth Longfellow's 1847 epic poem of the same name (see Morency, 2005) about Le Grand Dérangement Acadien $^{14}$ in 1755 . Given that Acadiens had a largely oral

14. As a sign of respect, "Acadien" is used in this paper with French spelling. 
history, their dispersal meant only lore of their plight remained once they themselves had physically vanished. Yet the fact of Acadien oral culture also means that there was an oral indigenous source text of the Grand Dérangement experience that only Acadiens themselves would know. Further, the Evangeline story is documented to have first been recorded in writing in Thomas C. Haliburton's An Historical and Statistical Account of Norva Scotia, which Longfellow is said to have consulted (Brasseaux, 1988, p. 9). Longfellow's English-language translation is known to have numerous factual, geographical, and historical errors such as: "peaceful" deportation, complete with hymns; Evangeline's improbable route north following the iconic American waterway, the Mississippi River, as opposed to the Atlantic coast back home (Longfellow, 1847, p. 128; LeMay, 1870, p. 129); her sojourn in American heartland-located Shawnee First Nation territories. As an American, Longfellow may not be viewed as a direct Acadien oppressor, nor representative of empire, however historical evidence indicates that New England-area governments and British authorities were complicit in organizing and executing Le Grand Dérangement, given that both believed Catholic Acadiens to be "unreliable citizens" due to their faith. ${ }^{15}$ Longfellow's lack of concern for historical accuracy when researching background for the translation of the narrative into the poem is also indicative of an exploitive, imperialist attitude towards minority cultures - facts were optional, so long as Longfellow's story remained compelling to readers, and fulfilled his desire to create a canon of so-called "fireside" poems and tall tales, in keeping with his other works of Americana such as The Song of Hiawatha or The Courtship of Miles Standish (Quetchenbach, 1998, p. 2). Longfellow's research was largely limited to archives at the Maine Historical Society, and to accounts by the victor, that is, representatives of the British or New England governments.

Despite the above-mentioned faults, dutifully reproduced in LeMay's ${ }^{16} 1870$ translation, the French-Canadian version remains a mainstay of the Acadien literary canon, servings both as a mournful

15. Recall that the Grand Dérangement took place in 1755; New England was populated by immigrant (and stanchly anti-Catholic) English Puritans, who had fled England to practice Calvinism, but who still had ties to England.

16. While LeMay was not Acadien himself, he was part of a fellow minority cultureFrench Canadians-who also suffered from their status as minorities. Therefore, he was well positioned to dialogue with the Acadien community. LeMay has been well documented (Textes choisis et présentés par Romain Légaré, LeMay, 1969) as having sought to create and bolster the French Canadian literary canon. 
testament to lost Acadien culture and a haunting reminder of history's misdeeds. LeMay was well known to support the plight of French minorities in Canada, and laid bare his love of the Acadiens in the preface to his translation:

Les Acadiens comme les Canadiens ${ }^{17}$ ont conservé le culte du souvenir $[\ldots]$. [...] comme sur les rivages de l'ancienne Acadie où sont restés les descendants des fils de la France, le voyageur retrouve le même [...] attachement que les persécutions les plus cruelles nont pu ébranler, la même urbanité, le même amour de la nationalité, amour sublime qui réunit toutes les amours et prête à un peuple quelque faible qu'il soit une énergie et une vigueur qui tiennent du prodige. (LeMay, 1870, p. 11)

LeMay was French Canadian (not Acadien), but can indeed be considered a suitable and genuine passive redressive translator, as he had extensive knowledge of Acadien culture and history, sincere affection for Acadien culture, and a stated interest in bolstering that culture through the retelling (translation) of what many consider to be the Acadien origin story-Le Grand Dérangement.

In LeMay's translation (next page), one can easily see passive redressive resistance via the characterization of les Anglais; the insertion of deportation panic (Longfellow's source uses “wandering," LeMay's uses "running" ("les femmes, les enfants courent de tous côtés"); the addition of poetic flourish (rhyming where no such structure is evident in the imperial source text); addition of familial/amour de la patrie reverence ("attendait son vieux père") and evidence of paradis perdu. While to the naked eye, this appears to be a faithful translation, passive redressive resistance is evident in the above-mentioned characteristics, which are clearly additions to LeMay's translated version. Of particular note here are the additions of a rhyming structure and references to family. The rhyming structure seems an innocuous translator's flourish, yet it lends the translation a childlike sing-songy quality that mocks the "Orientalizing" of the source text. While this rhyming format could be somewhat accounted for by the era's poetic norms, when taken with LeMay's more political additions (references to family, an allusion to patrimoine, and to Acadie itself) and his clear presence in the text, one can see passive redressive translation at work. Évangéline awaits her father, serenely, steadfastly, and as one reads Longfellow/LeMay's poems, one sees that she also serenely, steadfastly, searches for her patrie until at last she finds it.

17. Here, "les Canadiens" refers to French Canadians. 
Meanwhile had spread in the village the tidings of ill, and on all sides Wandered, wailing, from house to house

the women and children...

Long at her father's door Evangeline stood, with her right hand

Shielding her eyes from the level rays of the sun, that, descending,

Lighted the village street with mysterious splendor, and roofed each Peasant's cottage with golden thatch, and emblazoned its windows.

Lo! within had spread the snow-white cloth on the table;

There stood the wheaten loaf, and the honey fragrant with wild flowers;...
Cependant du village un grand trouble s'empare,

Car on sait des Anglais la conduite barbare;

Et les yeux tout en pleurs, tremblants, épouvantés,

Les femmes, les enfants courent de tous côtés.

Longtemps Évangéline attendait son vieux père,

À la porte, debout, sous l'auvent solitaire,

Tenant sa main ouverte au-dessous des yeux

Afin d'intercepter les reflets radieux [...]

Du soleil qui semblait vouloir jeter encor

Un long regard d'amour sur cette noble terre

Que venait d'enchaîner l'égoïste Angleterre.

Sur la table était mise une nappe de lin:

Déjà pour le souper étaient servis le pain, $[\ldots]$

(Longfellow, 1847, p. 84)
(LeMay, 1870 [Éditions du Boréal], p. 84)

French Canadian LeMay's passive redressive translation articulates experiences of life and history from within minority cultures. This stands in sharp contrast to Longfellow's idyllic narrative of romantic loss and wandering. As I hope this example in part proves, though the concept of passive and active redressive translation is relatively new to Translation Studies research, it has the potential to reframe existing translation analysis in a useful and innovative way.

\section{Active Redressive Translation}

Turning to active redressive translation, we need only to consider the many iterations of the Evangeline story by Acadienne author/ 
translator/playwright Antonine Maillet (among others), whose Evangeline-based works (La Sagouine; 1971, Évangéline Deusse, 1975) explore the character in a myriad of eras, social and cultural situations.

Maillet's numerous literary creations were mainly produced during the modern Acadien Renaissance (beginning in the 1950s and continuing on until roughly the 1970s), a period when Acadiens sought to both recapture and celebrate their rich and difficult heritage. Maillet's position as an Acadienne within her own culture permitted her to drastically change the quasi-sacred text that LeMay's Frenchlanguage Evangeline had become. This led her to create a new Evangeline character type that spoke to modern Acadien culture and Acadiens, while at the same time reflecting a shared and accepted heritage. The fact of her writing numerous Evangeline-themed works also bolsters the case for her use of redressive translation.

Her works prior to Evangeline Deusse tend to focus inward upon the Acadian people. Her most famous play, the dramatic monologue entitled La Sagouine, is, as has been shown, a search for identity couched in the theme of political protest (la contestation politique). (Weiss, 1977, p. 176)

In La Sagouine, gone is Longfellow's windswept, winsome heroine; Maillet instead makes Evangeline a humble yet wise everywoman, significantly, whose job is to clean up after others, and make clean that which is dirty (like history's account of her people, perhaps?). In Évangéline Deusse, the Evangeline character (and archetype) is one of a trio of elderly citizens in a Montreal park. Here, she acts as a conduit of sorts, bringing the others together through her subtle mentions or recollections of nation, identity and history. In terms of timing, proof that these works are examples of active redressive translation is found in the fact that the Acadien Cultural Renaissance was a period when Acadie was free of threats to its survival, and indeed was reviving its strength as a cultural, political, and socially unifying force. As a result, active redressive translations were created that unabashedly celebrated Acadienité.

Marginalized by geographic and economic factors, the Acadian regions remained culturally isolated until the middle of the $20^{\text {th }}$ century. Music and folklore were the only widespread forms of artistic expression [...]. The 1950s and 1960s saw a virtual explosion of Acadian culture in handicrafts, painting, song, dance, theatre, cinema and literature. (Doucette et al., 2015, n.p.) 
Yet another illustrative example of active redressive translation can be seen in the polyphony that is the numerous and varied translations of the Irish folktale the Táin Bó Cúailnge, or as it is known in English, the Cattle Raid of Cooley. A pagan, bardic, oral story recounted to early Catholic monks in the $5^{\text {th }}$ century, the Irish "reference" versions of this tale (the Book of Leinster, circa 1160; numerous unknown authors; the Lebor na hUidr, pre-12 $2^{\text {th }}$ century; numerous authors) are written in Medieval Irish that is nowadays virtually incomprehensible, save to a few scholars. Somewhat more "updated" versions of these manuscripts have been studied and "edited" by numerous scholars, key among them R.I. Best. Given their oral iterations, the Medieval Irish iterations, followed by the more modern English-language iterations, the Tàin is undeniably a series of retranslations (in the strict sense of translating-again). The story began to take on political tones during the Celtic Revival, as will be discussed below. ${ }^{18}$

The British Empire's first colony, Ireland had long been disparaged by the former as lacking cultural, social, and historical depth or relevance - this type of slander being a well-recognized pattern seen in colonization/settler colonialization processes across the globe. Yet in reality Irish oral history and tales are impressive, detailed, and historic. The Táin Bó Cúailnge is Western's Europe's oldest vernacular tale; it belongs to one of the four historical Irish story cycles ${ }^{19}$ detailing the region's rich, exciting, and varied ancient past. The stories were gathered from oral storytellers and recorded in print form by early Christian monks. There are roughly ten key Tàin retranslations, published between the 1870s and the 1970s, all based (to varying degrees) on the aforementioned medieval manuscripts (Tymoczko, 1999, p. 71) In the late $19^{\text {th }}$ and early $20^{\text {th }}$ century, a group of artistactivists fostered the Irish Literary Revival (Celtic Revival). This movement sought to cultivate popular support for Irish independence through acknowledgement and recognition of Ireland's rich and worthy cultural past by retranslating ancient Irish tales-including the Táin - for modern audiences. Temporally, this fits well with occurrences of active redressive translation.

18. Given that the global Modern Irish Gaeltacht (Irish-speaking community) is small, and space in this article is limited, I will use modern English-language retranslations of the Tàin for clarity.

19. The four ancient Irish story cycles are: the Ossianic, Ulster, Historical, and Mythological. The Táin Bó Cúailnge is from the Ulster cycle. 
Agitator/creators such as those acting within the Celtic Revival were creating in a time where it was possible for them to be activist, aggressive, and forthright about their political goals without fear of reprisal. Their translations and retranslations thus bear the marks of active redressive translation: bold re-imaginings of the source text, and the manifestation of polyphony via the production of numerous translated texts. Winifred Faraday's 1904 Tàin active redressive translation includes details from a very early English translation; said details are likely to bolster the historical weight of the text, giving credence precolonial/settler Irish culture as ancient and storied. Joseph Dunn's 1914 translation has a similarly academic tone to Faraday's iteration, but comprises additional details not included in other contemporary versions. ${ }^{20}$ The extensive character of Dunn's retranslation has led it to be considered one of the most exhaustive retranslations of the Tàin story; because it combined details and information from all the numerous Tàin manuscripts, over time it has become the reference for those interested in academic renderings of the tale. Ernest Windisch's 1914 German-language version is similar to Dunn's in its academic leanings, given the two authors' close collaboration. In contrast, Lady Augusta Gregory's 1902 work is a renamed, romantically styled, heavily modernized version that sought to create an accessible novellike offering destined for public consumption, with its sights set on popularity with the general masses.

The passage reproduced here (see next page) recounts an episode in the Tàin when Cuchulàin as a young child is attacked by a fierce and violent watch hound. As is clearly apparent, Lady Gregory's version (left-hand side) shortens the passage, focuses on Cuchulàin's resourcefulness and fearlessness in the face of mortal danger (despite being a child), and minimizes violence, whereas Dunn's version (righthand side) embraces gore, and notably has a highly stilted, formalsounding voice featuring archaic language. The aforementioned textual characteristics fit well with each translators' "needs": Gregory wanted a compelling, endearing story for the masses, which also bolstered sentiments of the inevitability of Irish nationalism, in the face of the reality of era's political frustration. Her active redressive translation allows readers to become swept up in the drama of the story, the heroic character Cuchulàin, and would almost certainly make for a lively,

20. "Contemporary" in this context referencing similarly themed works from the 1900 s to the 1920 s. 
exciting oral retelling! She also admits to heavily editing, another element of an active redressive translation: "I left out a good deal I thought you would not care about for one reason or another" (Gregory, 1902, p. vi). Her choice of the Tàin is also strategic: at its heart, it is a cautionary tale of resistance against intruders by cultivating the force that can only come from within-in this case, that force is Irishness itself. As for writing in English (versus Irish), Gregory was merely working in Ireland's most prevalent language, thus ensuring her active redressive translation received a wide audience.

$[\ldots]$ the hound heard him coming, and began such a fierce yelling that he might have been heard through all Ulster, and he sprang at him as if he had a mind not to stop and tear him up at all, but to swallow him at the one mouthful. The little fellow had no weapon but his stick and ball, but when he [Cuchulàin] saw the hound coming at him, he struck the ball with such force that it went down his [the dog's] throat, and through his body. Then he seized him by the hind legs and dashed him against a rock until there was no life left in him.

(Lady Gregory, 1902, p. 10)
The watch-dog descried the lad and bayed at him, so that in all the countryside was heard the howl of the watch-hound. And not a division of feasting was what he [the hound] was inclined to make of him [Cuchulàin], but to swallow him down at one gulp past the cavity of his chest and the width of his throat and the pipe of his breast. And the lad had not with him any means of defence, but he hurled an unerring cast of the ball, so that it passed through the gullet of the watch-dog's neck and carried the guts within him out through his back door, and he laid hold of the hound by the two legs and dashed him against a pillar-stone that was near him, so that every limb of him sprang apart, so that he broke into bits all over the ground.

(Dunn, 1914, p. 38)

On the other side of the Irish Nationalist coin, Dunn wanted an erudite, respectable, academic text that clearly placed Irish literary heritage on par with other Western European origin stories, and which actively refuted centuries of Imperial "study" that sought to disparage Irish culture, language, and art. Dunn himself was well known in Irish Nationalist camps, notably teaching at the Catholic University of America alongside fellow Irish Nationalists Thomas Joseph Shahan and P.J. Lennox. Dunn was a professor in Old and Middle Irish-Gaelic whose some thirty publications centred on Irish 
culture, language, and nationalism. With P. J. Lennox, Dunn wrote The Glories of Ireland, in which his nationalist intentions are laid clear:

we have been forced to the conclusion that the performances of the Irish race in many fields of endeavour are utterly unknown to most people, and they are not nearly so well known as they deserve to be. Hence there came to us the thought of placing on record, in an accessible, comprehensive, and permanent form, an outline of the whole range of Irish achievement during the last two thousand years. (Dunn and Lennox, 1914, p.i)

Though Dunn and Gregory's orientation were decidedly different, both show ample evidence of active redressive translation, for example in their respective styles: Gregory editing elements out on behalf of the reader; Dunn ensuring an exhaustive documentation of the tale for future Irish scholars. Both were stanchly nationalist in their politics, and both were very open about this fact. Cumulatively, the polyphony evident in the variety of works that comprise Tàin translations had the effect of encouraging Irish citizenry to discover their worthy literary past. There was literally something for every taste: academically inclined translations offered proof of Ireland's rich cultural heritage to the outside world, while romantic, stylized versions were popular with the masses. If only one version of a modernized Táin had been produced - say, only the academic version - it is quite possible that popular Irish imagination may not have been as inspired to embrace the folktale, given that Dunn's academic translation lacks the lyrical, romantic, and accessible features that Gregory's iteration possesses. This reinforces active redressive translation's emphasis on producing numerous translations that reflect the wide range of voices that polyphony embodies, in order to meet the needs of a wide-reaching audience; its also reflects the varied political uses and interpretations available for the source text.

\section{Conclusion}

At the present time, despite significant differences in ideological orientation, "retranslation" is used as a catch-all term to refer to translating-again and translating/translating-again-for-political-purposes. I propose that Translation Studies henceforth adopt the term "redressive translation" exclusively for the category of retranslating/ translating-again-for-political-purposes; "retranslation" would then be applied to apolitical translating-again texts. 
Further, redressive translation is part of the more generalized phenomenon of resistance in translation; the two terms are indeed often linked due to their shared functions and manifestations. Yet, redressive translation differs from generalized resistance in translation because the former expressly sets out to foster redress within the minority communities that it dialogues with while also acknowledging the existence of an indigenous source text. Additionally, it requires the creation of multiple iterations of redressive texts to foster polyphony, which at once destabilizes the authority of the imperial source text, and also enables a wide range of previously-silenced, minority voices to be heard. Lastly, redressive translation's success is measured by the degree of acceptance these translations achieve within the communities it seeks to dialogue with (not "speak for").

Redressive translation encompasses passive and active redressive translation, both of which have individual, distinctive features. Most notable of these are the existence of an indigenous source text, and the requirement of community acceptance from the minority whose resistance and woes are being articulated. In terms of timing, passive redressive translation occurs when oppressed groups are becoming aware of their desire for independence, but may not have full liberty to express this desire. As a result, passive redressive translations often appear to be overzealously faithful, a style which in fact mocks imperial, essentialist assertions by magnifying them through repetition. Advancing along the trajectory towards the postsettler/postcolonial era is the appearance of active redressive translation, which boldly asserts once-oppressed minorities' desire to articulate authentic selfimages through active redressive translations. These texts may appear as sweeping rewritings, and feature massive divergences from imperial source texts, as minority/minoritized communities redress and rehabilitate translations to reflect their authentic selves.

\section{References}

Anderson, Benedict (2006). Imagined Communities: Reflections on the Origin and Spread of Nationalism. London, Verso.

Armstrong, Paul B., ed. (2016). Heart of Darkness, by Joseph Conrad. $5^{\text {th }}$ Norton Critical Edition, New York, W.W. Norton \& Company.

Baker, Mona (2006). Translation and Conflict: A Narrative Account. London and New York, Routledge.

Baker, Mona and Kirsten Malmkjær, eds. (2008). Routledge Encyclopedia of Translation Studies. $2^{\text {nd }}$ ed. London and New York, Routledge. 
Bandia, Paul (2008). Translation as Reparation. Manchester, St. Jerome.

Bakhtin, Mikhail (1984). Problems of Dostoevsky's Poetics. Trans. and ed. Caryl Emerson. Minnesota, University of Minnesota Press.

Bascara, Victor (2003). "Cultural Politics of Redress: Reassessing the Meaning of the Civil Liberties Act of 1988 after 9/11." Asian American Law Journal, 10, 2, pp. 185-214.

Berman, Antoine (1990). "La retraduction comme espace de la traduction." Palimpsestes. 4, pp. 1-7.

Best, R.I. et al., eds. (1954-1983). The Book of Leinster, formerly Lebar na Núachongbála. 6 vols. Dublin, Dublin Institute for Advanced Studies.

Best, R.I. and Osborn Bergin, eds. (1929). Lebor na bUidre [Book of the Dun Cow]. Dublin, Hodges, Figgis, \& Co.

Bhabha, Homi (1994). The Location of Culture. London and New York, Routledge.

Bourdieu, Pierre (1986). "The Forms of Capital." In J. Richardson, ed. Handbook of Theory and Research for the Sociology of Education. Westport, Greenwood, pp. 241-58.

Brasseaux, Carl (1988). In Search of Evangeline. Birth and Evolution of the Evangeline Myth. Thibodaux, Blue Heron Press.

Conrad, Joseph (1899). "Heart of Darkness." Blackwood's Edinburgh Magazine, vol. CLXV, February, pp. 193-220, March, 479-502, April, pp. 634-657.

Cox, Amanda Leigh (2009). Articulating Resistance: Translating Acadie and Ireland as Postcolonial and Subaltern. Masters Thesis, Département d'études françaises, Concordia University.

Derrida, Jacques. (1976). Of Grammatology. Trans. Gayatri Chakravorty Spivak. Baltimore and London, Johns Hopkins.

Doucette,Leonard E.et al. (2015). “Culture of Acadia.” Canadian Encyclopedia. [http://www.thecanadianencyclopedia.ca/en/article/culture-of-acadia/].

Dunn, Joseph (1914). The Ancient Irish Epic Tale the Tàin Bo Cualgne-The Cualgne Cattle Raid. Whitefish, Kessinger.

Dunn, Joseph and P. J.Lennox, eds. (1914) The Glories of Ireland. Washington, Phoenix Limited.

Faraday, Winifred (1904). The Cattle Raid of Cualnge, Tain Bo Cuailnge: An Old Irish Prose Epic. Whitefish, Kessinger.

Gregory, Lady Augusta (1902). Cuchulain of Muirthemne. Whitefish, Kessinger.

Gürçağlar, Shenaz Tahir (2008) "Retranslation." In M. Baker and K. Malmkjær, eds. Routledge Encyclopedia of Translation Studies. $2^{\text {nd }}$ ed. London and New York, Routledge.

Halbwachs, Maurice (1993). On Collective Memory. Trans. Lewis A. Coser. Chicago, University of Chicago Press.

Heywood, Andrew. (2013). Politics. $4^{\text {th }}$ ed. Basingstoke, Palgrave Macmillan. 
Jakobson, Roman (1959). “On Linguistic Aspects of Translation.” In R.A. Brower, ed. On Translation. Cambridge, Harvard University Press, p. 232-239.

LeMay, Pamphile (1969). Textes choisis et présentés par Romain Légaré. Montreal, Fides.

Longfellow, Henry Wadsworth (1909). The Poems of Henry Wadsworth Longfellow 1823-1866. New York, JM Dent and Sons Ltd.

Maillet, Antonine. (1971). La Sagouine. $1^{\text {st }}$ ed. Montreal, Éditions Leméac. Maillet, Antonine (1975). Évangéline deusse. Montreal, Éditions Leméac.

Merriam-Webster Dictionary (n.d.). "Indigenous." [https://www.merriamwebster.com/dictionary/indigenous].

Merriam-Webster Dictionary (n.d.). "Redress." [https://www.merriamwebster.com/dictionary/redress].

Mezei, Kathy, Sherry Simon and Luise von Flotow, (2014). "Introduction." In K. Mezei, S. Simon and L. von Flotow, eds. Translation Effects. The Shaping of Modern Canadian Culture. Montreal, McGill-Queen's University Press, pp. 3-27.

Morency, Jean, ed. (2005). Henry Wadsworth Longfellow - Évangéline Traduction française par Pamphile LeMay (éd. bilingue). Montreal, Les Éditions du Boréal.

Niranjana, Tejaswini (1992). Siting Translation: History, Post-Structuralism, and the Colonial Context. Berkeley, University of California Press.

Nolke, Henning (2017). Linguistic Polyphony. The Scandinavian Approach: ScaPoLine. Leiden, Brill.

Quetchenbach, Bernard (1998). Evangéline: An Overview. Fort Kent, University of Maine.

Said, Edward (1978). Orientalism. London, Penguin.

Simon, Sherry (2005). "Presentation." TTR, 18, 2, pp. 9-16.

Simon, Sherry (2014). "Translating Cultural/Race Politics.” In K. Mezei, S. Simon and L. von Flotow, eds. Translation Effects. The Shaping of Modern Canadian Culture. Montreal, McGill-Queen's University Press, pp. 5062.

Spivak, Gayatri (1988). "Can the Subaltern Speak?" In C. Nelson and L. Grossberg, eds. Marxism and the Interpretation of Culture. Basingstoke, MacMillan Educational, pp. 271-313.

Tymoczko, Maria (1999). Translating in a Postcolonial Context: Early Irish Literature in English Translation. Manchester, St. Jerome.

Tymoczko, Maria, ed. (2010). Translation, Resistance, Activism. Amherst, University of Massachusetts Press.

Venuti, Lawrence (1998). The Translator's Invisibility: A History of Translation. London and New York, Routledge.

Weiss, Jonathan M. (1977). "Acadia Transplanted: The Importance of Evangeline Deusse in the Work of Antonine Maillet." Colby Library Quarterly, 13, 3, pp. 173-185. 
Wolfe, Patrick. (1998) Settler Colonialism and the Transformation of Anthropology: The Politics and Poetics of an Ethnographic Event. Writing Past Colonialism. London and New York, Bloomsbury.

Amanda Leigh Cox Montreal (Quebec), Canada shesfoundintranslation@gmail.com 